\title{
Research on the Blended Teaching Mode of College Ideological and Political Courses Against the Background of "Internet Plus"*
}

\author{
Liya Luo \\ China University of Political Science and Law \\ Beijing, China 100088 \\ School of Marxism \\ Guizhou University of Finance and Economics \\ Guiyang, China 550025
}

\begin{abstract}
In December 2016, General Secretary of the CPC Central Committee, President of the State Council and Chairman of the Central Military Commission Xi Jinping delivered an important speech at the National Conference on Ideological and Political Work in Colleges and Universities in Beijing, emphasizing that "to do a good job in ideological and political work in colleges and universities, we must change according to incident, improve with time and refresh according to situation. We must use the main channel of classroom teaching, ... and use new media and new technologies to make the work alive, to promote the integration of traditional advantages of ideological and political work with information technology, and enhance the sense of the times and attractiveness. ${ }^{1}$ This paper expounds the characteristics and concepts of blended learning, the influence of the development of "Internet plus" on the field of education, and the construction of the blended learning mode of ideological and political courses in colleges and universities, trying to provide multiple choices for the scientific and reasonable teaching mode of ideological and political courses in colleges and universities.
\end{abstract}

Keywords-Internet plus; blended learning; ideological and political teaching mode

\section{INTRODUCTION}

At present, the ideological and political courses in China's colleges and universities need to solve the problem of lack of "head-up rate" with good "attendance rate" in the process of teaching. In order to solve this problem, it is necessary to use various means and adhere to the diversified training mode. The person in charge of the Department of Social Sciences of the Ministry of Education pointed out that the main task of the reform of teaching methods is to improve the affinity and pertinence of the teaching of ideological and political courses, encourage the active initiative of students to learn, strengthen the interaction between students and teachers, reasonably determine the

*Project Source: Teaching Quality and Teaching Reform Project of Guizhou University of Finance and Economics (JG201706)

Young Teachers Talent Project of 2016 Guizhou University of Finance and Economics amount of teaching, promote the deep integration of modern information technology and ideological and political teaching, and explore the practice of online and offline blended teaching mode when he answered the reporter's question on the "Overall Plan for the Annual Specialized Work of the Ideological and Political Theory Courses of Colleges and Universities in 2017". ${ }^{2}$ There is no doubt that it is of great significance to improve the quality of teaching in the ideological and political course, but how to achieve this goal has become a very serious practical problem in front of many front-line teachers in many colleges and universities.

\section{IINTERNET PLUS" AND BLENDED LEARNING}

\section{A. The Educational Application of "Internet Plus"}

The concept of "Internet + " was first proposed by Premier Li Keqiang in the 2015 government work report, and later became a hot spot of concern to all sectors of society. "Internet $+"$, the combination of the Internet and other traditional industries, is a new development model for other traditional industries to leverage Internet technology. As a national strategy, "Internet + " has now become an important driving force for the innovation and development of China's education and culture. Its application in education has brought tremendous influence to the educational elements of China, which in turn changed the traditional teaching mode. ${ }^{3}$

With the development of information technology and networks, the types of classrooms have also changed. A variety of classroom types appear alternatively and play an important role in the teaching process, including: traditional classrooms, network-assisted classrooms, blended classrooms (flipped classroom and bi-classrooms, etc.) and online courses (MOOC and SPOC, etc.) and other teaching models. Emerging social media (such as WeChat and Weibo, etc.) also play an important role in virtual learning scenarios Nowadays, the development of "Internet + " has shown an unstoppable trend. Its development has also promoted changes in the field of education, and affected people's work, 
study and life, especially the thinking and behavior of contemporary college students. Therefore, teachers of ideological and political education in colleges and universities must develop their thinking, innovate ideas, change their methods, and follow the trend to participate in the educational reform against the background of "Internet $+"$.

\section{B. Blended Learning in the Context of "Internet Plus"}

1) The concept and characteristics of blended learning: As one of the earliest literature introducing the concept of blended learning into China, the "New Development of Educational Technology Theory from perspective of Blending Learning" of professor He Keqin mentioned (I) that blended learning is a combination of traditional learning methods and digital learning methods, which is a new way of learning that not only can play the leading role of teachers in the teaching process, but also reflect the subjective position of students in the learning process. ${ }^{4}$ The purpose of blended learning is to achieve the combination advantage, which means to select and combine teaching modes/strategies/methods according to specific teaching objectives and situations, absorb the advantages of different teaching modes/strategies/methods, and construct the most appropriate teaching structure to achieve efficient learning and deep learning. ${ }^{5}$ In terms of the content of blended learning, the current consensus in the education circles at home and abroad is that blended learning is a diversified learning model that combines the time, occasion, or progress of traditional teaching and self-controlled learning in schools. With the offline and online teaching mode, it uses the informatization technology to fully reflect the main role of students in learning, and can play the leading role of teachers, thus achieving the essential pursuit of education.

At the same time, blended learning has the following characteristics: rich teaching information carrier, fast dissemination of teaching content, wide range of teaching influence, and many teaching exchange methods. Compared with the traditional education model, blended learning can easily realize two-way communication and multi-directional communication because of the choice of teaching modes. The audience can choose the course they want to learn according to their own needs, without considering the limit of time and space conditions. The popularity of digital information technology and the Internet, and the use of a variety of Internet terminals enable blended learning to synchronize the information of educators and educated individuals with personalized, multi-selective, flexible and refined learning methods.

2) "Internet plus" and blended learning: In fact, the blended teaching in the context of "Internet + " is not only a simple combination of offline learning and online learning, but a new teaching mode combining multiple teaching elements, multiple teaching situations, and a large number of teaching resources through the advantages of the Internet. The external manifestation of education in the context of
"Internet $+"$ is the use of new generation information technologies such as mobile Internet, big data, and the Internet of Things to achieve a mix of online and offline education; its inherent nature is to achieve better teaching results by complementing the advantages and deep integration of the two.

\section{Construction of Blended Teaching Mode OF IDEOLOGICAL AND POLITICAL COURSES AGAINST THE BACKGROUND OF "INTERNET PLUS"}

In January 2018, China Internet Network Information Center (CNNIC) released the 41st "Statistical Report on the Development of China's Internet Network" in Beijing. Up to December 2017, the number of Internet users in China reached 772 million, with a popularizing rate of $55.8 \%$, exceeding the global average $(51.7 \%)$ by 4.1 percentage points, and exceeding the Asian average (46.7\%) by 9.1 percentage points. ${ }^{6}$ The penetration of the network in the aspect of life changes the way we learn. The dissemination of knowledge and the acquisition of information break through the boundaries of time and space, making it possible for blended teaching mode in ideological and political courses in colleges and universities.

\section{A. The Advantages of Blended Teaching in Ideological and Political Courses Against the Background of "Internet Plus"}

At present, it is precisely the period when the socialist market economic system is gradually established and perfected. The transformation of the economic system has had a wide and profound impact on China's political, economic, and cultural fields. China is currently in the midst of the period with aggravating social problems, when the students' ideological character also showed a diversified situation, showing a strong tendency of individualized development. This change poses corresponding challenges to the traditional ideological and political education model of colleges and universities. Applying blended teaching to the teaching of ideological and political courses in colleges and universities can realize the complementary advantages of multiple teaching spaces and enhance the teaching quality and effect of ideological and political courses. ${ }^{7}$

First of all, the ideological and political education in the era of "Internet + " has broken through the boundaries of time and space with the help of multiple teaching platforms. It can be carried out at anytime and anywhere, extending the teaching of ideological politics from the traditional classroom to the outside of the classroom, and realizing the fusion of systematic learning and fragmentation learning. Through the dissemination of ideological and political courses by various intelligent terminals with Internet as a medium, college students can acquire a large amount of knowledge and information in a timely and convenient manner, and can freely choose the information of their own interest according to their own needs. The carrier of online classroom diversification also provides media support for the teaching of ideological and political education to achieve "teaching people according to their abilities" and "teaching students according to their aptitudes". With the 
development of information technology, it can broaden the educational ideas cultivated by college students and enhance the study effect of ideological and political courses in colleges and universities.

Secondly, "Internet + " makes the practice links that were difficult to implement in the classroom in the past be realized through blended learning. At the beginning of the course, the content of the practice is conveyed to the students by using the flipped classroom or the WeChat class, and the students are guided to use the spare time to carry out the practice. In the middle of the course, we can make big data analysis on the problems generated in the students' practice through the Internet, which help teachers to grasp the degree of students' understanding of theoretical knowledge points in college ideological and political courses, as well as understand the aspects of students' interest, to help students apply the theoretical knowledge learned in the classroom to the practical process based on the analysis of targeted adjustments; in the later period of courses, the classroom will show the results of the practice and share the practical experience through online classes. This kind of intuitive learning method will make students more immersive and empathetic, which will undoubtedly increase students' enthusiasm and initiative in the ideological and political study.

Finally, the emerging media and virtual classrooms appearing under the background of "Internet +" broke the limitations of the traditional relationship between teacher and student, and further highlighted the autonomy and interaction of both sides. Under the blended teaching mode of colleges and universities in the context of "Internet +", the relationship between teacher and student has been greatly improved. In the virtual classroom, students do not need use real names, so they can ask questions or communicate with teachers on an equal basis. Teachers can regard students as independent learning individuals to tap students' enthusiasm for learning, ensure students' differentiation in the learning process, and allow students to develop personally. In the communication under the equal status, people can do what they want, and express their own opinions. This kind of communication will inevitably lead to different perceptual cognition and value judgments of students on the same course. They can collide out the spark of wisdom and flash the star of opinion. It can enhance the persuasiveness, attractiveness and appeal of ideological and political teaching.

\section{B. The Realistic Dilemma of Blended Teaching in Ideological and Political Courses Against the Background of "Internet Plus"}

The blended learning mode of ideological and political courses in colleges and universities integrates the advantages of both online learning and offline learning, and has achieved good results in teaching practice. However, due to the lack of theoretical reserves, inadequate institutional environment, insufficient teachers' ability, and inadequate use of data capture and mining techniques, some reforms have fallen into the predicament of "jollification outside and ineffectiveness inside". ${ }^{8}$
With the popularization of multimedia teaching and the construction of the school's Internet network, the teaching methods of ideological and political courses in colleges and universities have become more abundant, which has also brought about the classroom teaching tendency of paying attention to technical means and ignoring teaching content in the blended learning of ideological and political courses. In the classroom teaching, in order to enhance students' interest, some ideological and political teachers used multimedia means to display teaching resources such as pictures, animations and micro-videos, but ignored the control of teaching content, which led students to enjoy the "feast" of hearing and vision in traditional classrooms, but the theoretical knowledge has not yet reached their hearts. On the other hand, some teachers pay insufficient attention to information technology. It is difficult to realize the teaching requirements of diversified teaching methods and diversified evaluation systems in the teaching practice of ideological and political courses. This is also the reason for the poor result of the teaching effect of the blended teaching mode of ideological and political courses. In addition, due to the comprehensive use of various teaching methods, especially the extensive use of mobile tools based on mobile Internet technology, students' original fixed learning places are broken, and the uncontrollability of mobile tools makes the learning process difficult for students to monitor. It has caused more free learning and decentralized learning, so the teaching effect is out of the question.

\section{Construction of the Blended Teaching Mode of Ideological and Political Courses Against the Background of "Internet Plus"}

1) Updating the teaching concept of ideological and political education in colleges and universities: The "Internet +" era is a new era based on the impact of emerging information technologies such as mobile Internet, big data, and the Internet of Things. After entering the "Internet + " era, the widespread use of the Internet has had different degrees of impact on economic development and social operations, but it also subtly influenced the traditional college ideological and political teaching mode. Based on the background of "Internet +", the ideological and political teaching in colleges and universities should uphold the teaching philosophy of cultivating students with both ability and political integrity. It should not only pay attention to the theoretical teaching of the classroom, but also strengthen the cultivation of students' moral quality in social practice. At the same time, in the teaching process, we must fully understand that technology is an important means of disseminating knowledge. When mastering the new teaching technology, we must have a solid theoretical accumulation to teach the ideological and political class well. In short, only by adapting to the development trend of the "Internet +" era and updating the educational concept of college ideological and political education, can we broaden our horizons, lay a foundation, and provide effective support for the cultivation of talents in the new era. 
2) Establishing a database of teaching resources for ideological and political education in colleges and universities: The teaching content is an important basis for teaching resources. If there is no rich teaching content as teaching support, the advanced teaching concept and the high-quality teaching staff can't exert their effect. At present, the teaching resource database specifically for the teaching of ideological and political courses in colleges and universities has not yet been established. Therefore, we can use the big data technology in the Internet based on the "Internet +", and summarize, analyze and then extract the data information that conforms to the education needs of ideological and political course from the vast amount of data through the measurement, collection and analysis of relevant data in the theoretical study and practice of students to provide support for the establishment of the database of ideological and political teaching resources in colleges and universities, and better realize the precision of ideological and political teaching in colleges and universities.

3) Enhancing the ability of teachers to use digital learning platforms: The development of education transformation is the requirement of the times. With the popularization and application of the digital learning platform, higher requirements are placed on the data literacy of teachers. For teachers, the establishment of the "Internet $+"$ era digital learning platform has changed the teacher's one-way and straight-line curriculum teaching role in the traditional teaching mode, and then transformed it into a teaching interaction type of "teaching students according to their aptitude." Therefore, the ability of the teachers' using digital learning platform will affect the actual effect of the reform of the ideological and political education mode in colleges and universities. Only by skillfully using educational information technology can make the online course attract people and the offline teaching guide and inspire people, and increase the interaction and communication between students and teachers, thus giving full play to the role of "Internet + " information technology in promoting the reform of the ideological and political education mode in colleges and universities.

\section{CONCLUSION}

The arrival of the "Internet + " era will inevitably promote the reform of the ideological and political education mode in colleges and universities. Although we can't immediately describe the contours after the change, we can predict that "Internet + " will have a profound impact on the blended learning mode of ideological and political courses in colleges and universities through exploring the scientific positioning of the relationship between the "Internet +", blended learning and the ideological and political teaching mode of colleges and universities and the organic combination on this basis. It can be seen that the research on the blended learning mode of ideological and political courses in colleges and universities under the background of "Internet + " helps us to enrich and innovate the traditional theoretical thinking mode of ideological and political education in colleges and universities; in practice, it helps us improve ideological and political education affinity and pertinence, better play the guiding role of teachers and the main role of students, enhance students' initiative and consciousness in accepting ideological and political education, so as to better teach students in accordance with their aptitude and promote the cultivation of innovative talents in the information age.

\section{REFERENCES}

[1] Xi Jinping. Speech at the National Conference on Ideological and Political Work in Colleges and Universities [N]People's Network, 2016-12-09.

[2] Ministry of Education. 2017 overall plan for the teaching quality of college ideological and political theory courses [N]. Ministry of Education website, 2017-05-01.

[3] Yang Xue, Jiang Qiang, Zhao Wei. Big data analysis and education reform - thoughts on the 15th International Forum on Educational Technology in 2016[J]. Modern Distance Education, 2017(2):62-75 .

[4] He Kekang. Overview on the new development of educational technology theory from blending learning(II) $[\mathrm{J}]$. Information Technology Education in Primary and Secondary Schools, 2004(4):10-15.

[5] Hu Liru, Zhang Baohui. Blended learning: teaching structure design towards technology strengthening[J]. Modern Distance Education Research, 2016(4): 21-31.

[6] Statistical Report on the Development of China's Internet Network [R], China Internet Network Information Center, 2018-1-31.

[7] Yang Zhichao. Analysis on the construction path of the blended learning mode of ideological and political theory courses in colleges and universities[J]. Studies in Ideological Education, 2016(6): 69-73.

[8] Peng Feixia, Yang Wen. How to deepen the depth of learning in blended learning - how education big data supports learning analysis[J]. Modern Distance Education, 2017(2): 31-39. 